\title{
Elder Abandonment in Mexico: Unattended public health problem
}

\author{
Abandono del adulto mayor en México: problema desatendido de la salud pública
}

\author{
Aura Cristina Gómez-Cardenas ${ }^{a}$
}

Received: 07/09/2018, Accepted: 11/12/2018, Published: 05/01/2019

\begin{abstract}
:
Aging is occurring at a speed higher than that experienced historically by the developed countries. Older population will grow three times faster than the growth rate of the total population. The largest increases will happen in countries that do not now show the highest percentages of people over the age of 60, as in the case of Brazil, Mexico and the Dominican Republic. However, in countries like Honduras and Paraguay this population grows at higher rates with respect to other countries. Public health in Mexico and Latin America faces the challenge of reforming health systems in a way that they can face a double burden of disease, represented by the increasing prevalence of chronic diseases and their complications, in addition to the persistence of transferable infectious diseases and those associated with nutritional problems. For this reason, the perception of abandonment of the older adults, it is appropriate to define some concepts implicit in the sociodemographic characteristics that are reflected in the statistics of each Latin American country and especially in Mexico, because their population pyramid is increasing with this age-specific disease, generating that due to multiple economic and physical consequences, among others, abandonment becomes a consequence frequently neglected.
\end{abstract}

Keywords:

Abandonment, Older Adult, Public Health

\section{Resumen:}

El envejecimiento está ocurriendo a una velocidad mayor que la experimentada históricamente por los países desarrollados. La población adulta mayor crecerá tres veces más rápidamente que el índice de crecimiento de la población total.

Los mayores incrementos se darán en países que no muestran en la actualidad los mayores porcentajes de personas mayores de 60 años, como es el caso de Brasil, México y República Dominicana, en países como Honduras y Paraguay esta población crecerá incluso a tasas que son superiores con respecto a otros países.

La salud pública en México y Latinoamérica enfrenta el reto de reformar sus sistemas de salud de manera que se pueda afrontar a la doble carga de enfermedad, representadas por la creciente prevalencia de las enfermedades crónicas y sus complicaciones, además de la persistencia de las enfermedades infecciosas transmisibles y aquellas asociadas con los problemas nutricionales.

Por esta razón, la percepción de abandono del adulto mayor, es propio definir algunos conceptos implícitos en las características sociodemográficas que se reflejan en las estadísticas propias de cada país de Latinoamérica y especialmente en México, debido a que su pirámide poblacional va en aumento con esto las enfermedades propias de la edad, generando que por múltiples consecuencias ya sea económicas, físicas entre otras el abandono se convierte en una consecuencia y a esta no se le da la importancia que se debe.

Palabras Clave:

Abandono, Adulto Mayor, Salud Pública

\section{INTRODUCTION}

Aging is occurring at a speed higher than that historically experienced by the developed countries. Older population will grow at a rate of $3.5 \%$ in the period $2020-2025$, three times faster than the growth rate of the total population. The largest increases will happen in countries that do not show now the highest percentages of people over the age of 60 years old, as is the case of Brazil, Mexico and the

\footnotetext{
Corresponding author: Fundación Universitaria Escuela Colombiana de Rehabilitación, Bogotá, Colombia, Phone Number: +52 
Dominican Republic, but in countries like Honduras and Paraguay this population will grow even at rates higher than $4 \%$ between 2000 and $2025 .^{1}$

Aging is part of a series of phenomena that occur throughout the life cycle from conception until death. However, despite being a natural process known by all human beings, it is difficult to accept it as an innate reality of the human being. ${ }^{2}$

The United Nations and the World Health Organization in their intention to implement international criteria have conventionally established the age of 60 years old as the age of onset of old age. Currently, there are serious questions about whether it is convenient or not to establish a fixed age as the beginning of the aging process, as a standard measure. ${ }^{3}$

This process started in developed countries several decades ago and came later to countries in Latin America, such as Mexico. It is explained by the demographic transition that appears when the elderly population grows at a higher rate than other age groups, due to the social programs of fertility reduction and advances in medical technology, which result in lower levels of mortality. ${ }^{4}$

The majority of Older Adults (EA) have a social and economic context of poverty increase in Mexico. A situation that is emphasized in a rural or indigenous environment. ${ }^{4}$

In Mexico, there is a small number of studies on domestic violence, mainly in the violence against $E A$, for this reason, it is necessary to have validated, reliable and easy instruments to implement by the family doctor. It is essential to value the presence of emotional disorders, the phenomenon of abandonment and the functionality of families, in the cases of elder abuse. ${ }^{5}$

The aging of population requires, therefore, a comprehensive public health response, very little is known about the strategies that are currently effective, aging is a global phenomenon that has enormous economic, social and political consequences. ${ }^{2}$

\section{CONCEPT OF AGING}

A man, throughout time, has varied stages of development, including prenatal care, infancy, childhood, adolescence, youth, adulthood, and old age, each of them has a vital importance particularly the old age, as the last stage of human life, in which he/she has reached its maximum expression of relationship with the world, he/she has reached full maturity through a large number of experiences acquired during moments and instants enjoyed. ${ }^{7,8}$

Even though, connotations about the old age in a social context are not always perceived as positive according to the following definition: Old age is the final stage in the process of aging. Equivalent to live many years, in comparison with other people of the same population group. $^{9}$

Its limits, except death, have been and always are imprecise and dependent; however, the definition of EA depends on the context and the group of people to which it refers. On the other hand, it refers to the last stage of human life, is the state of a person when due to an increase of age he or she suffers from a biological decline of his/her body. ${ }^{9}$

\section{OLD AGE}

Some relate the concept of old age with pejorative terms such as decrepit and deteriorated; other times it is associated with the definition of third age, therefore, in the social field, is the change of biological transformation, which is displayed to others, going to statements such as the old age or fourth age - is bounded by factors of biological changes plus determinants of psychological change as the age of the subject increases. As we noted recently, the term elder is assigned only to that particular genre of organisms that we call people, in the last stages of life. ${ }^{10}$

Also, to refer to the concept of old age, in some communities they have in mind the characteristics and physical states of older people, by looking at the limits of the level of activity or participation in the activities of the society. It refers to the stage that includes the end of life, which starts at about 60 years old. ${ }^{11}$

This age is characterized by a growing decline of physical strength, which, in turn, leads to a sensitive and progressive decline of mental activity. The individual starts losing interest for life and starts living remembering 
the past since the present and the future now offer very few prospects. ${ }^{11}$

\section{AGING}

Today, in society, the number of older people rises rapidly, more than other social groups, becoming a challenge for the states, not only from the social aspect but also from an economic point of view, due to the increase of life expectancy in older people. It would be ideal to enjoy life with quality in order to continue to be active doing activities that give them pleasure and independence, for this reason. ${ }^{12}$

There is something called active aging which arises in contrast to the pathological aging, this difference arises from circumstances such as the fact that not all people age in the same way, demonstrating a significant rate of older people that age favorably. The above refers to the concept of satisfactory aging, with success or authority, which arises from the investigation of the enriching phenomena occurring during aging like the learning potential, the concept of wisdom. ${ }^{12}$

Therefore, understanding the term of aging as a process that not only must be related it with time, since through it, there are countless physical and physiological changes that slowly deteriorate the vital functions. From another point of view, there are external factors such as the environment and personal factors. The decline is related to the deterioration in the function of some organs, with the reduction of sensory perception and the speed of reaction to stimuli. ${ }^{13}$

It is a time of change: the physical appearance changes progressively, gray hair and wrinkles appears, also changes in the distribution of body fat; there are also observed significant changes in the functioning of organs and body systems. ${ }^{13}$

\section{THE THIRD AGE}

The third age, according to the United Nations, starts when people get to the age of 60 years old. Today, there are two opposing models to understand the old age. The first negative model identifies the old age as the loss of biological, psychological, social and cultural abilities that characterize the last phase of life which ends with death. The second one is the successful model, which refers to the specific and positive development of the person, in which the old age is conceived as another stage of the life cycle. ${ }^{14}$

\section{ELDER ABANDONMENT}

Defined as the purposeful and permanent desertion of an elderly person. Occurs when a person who has assumed the responsibility for providing care to an elderly individual desert that individual. ${ }^{15}$

The abandonment occurs in all social sectors, there are no official figures that allow making a more in-depth analysis on the subject, however, when we refer to abandonment, it is not only about lower-middle-class or low-income abandonment, where virtually the person EA is taken out of his/her home and never know about him/her again, but it is also the abandonment on behalf of the family taking EA to retirement homes or institutions and then no longer take charge of their support. ${ }^{16,17}$

\section{KINDS OF ABANDONMENT}

Total abandonment: This type of abandonment is when older adults have no one to take care of them and cover their basic needs, forced to depend on the society's charity, by means of alms. ${ }^{15}$

Partial abandonment: Partial abandonment is most noticeable in families that have the means to pay a private home, where they contribute a certain amount and the EA is practically hospitalized in that place, and the relationship between the family and the older person is each time more banished as most families will visit the EA occasionally, making the EA feel lonelier with each passing day. ${ }^{18}$

Physical Abandonment: This type of abandonment can be seen in families who only pay the corresponding monthly payment in a private home, completely forgetting that they have to visit the EA, physically neglecting him/her. In low-income families, older adults are totally abandoned, leading older adults to become indigents. An EA in a situation of abandonment must be understood as: a person older than 65 years old, who has no subsistence means, who has no food or health care, who is homeless, who suffers from physical or mental mistreatment from their relatives or third persons, who is neglected. ${ }^{19}$ 


\section{PUBLIC HEALTH IN OLD AGE}

During the second quarter of 2016, the population aged 60 or more years old represents $33.6 \%{ }^{7}$

The changes in the demographic components, fertility, mortality and migration, including the international migration, have determined the volume and the age structure of the population of Mexico, that step from approximately 16.5 million inhabitants (8.4 million of women and 8.1 of men) in the 30's last century, to about 119.7 million in 2014 (61.2 million of women and 58.4 of men). ${ }^{7}$

It is expected to increase a little more than 150 million in 2050 (77.9 million of women and 72.9 of men), according to the projections of the National Population Council (CONAPO). ${ }^{7}$

Also, the aging process was moved from the private to the public space because of vulnerability situation of the EA in Mexico, reflected in poverty, discrimination and marginalization of this sector of the population, as we shall see in the next section. ${ }^{4}$

The aging of the population is a success of societies and of the Public Health caused by the improvement of health and living conditions, and at the same time it generates new challenges in the health, social and economic fields. ${ }^{20}$

The aging of the population in countries of Latin America and developing countries, has happened in a much more accelerated way compared to Europe, making the services insufficient for older people in these regions. ${ }^{17}$ The epidemiological profile and social determinants of this population group generate complications that require innovative, comprehensive, evidence-based and costeffective responses to generate a better life quality and decrease disability and cost associated to health care. ${ }^{21}$ There are multiple public health programs around the world. These programs need to be consistent with the challenges currently faced by the discipline. In spite of this, there is little offer of specializations in the process of aging and old age affecting the world's population. ${ }^{22}$

Public health in Mexico and Latin America faces the challenge of reforming their health systems so that it can face the double burden of disease they face, represented by the rising prevalence of chronic diseases and its complications, in addition to the persistence of transferable infectious diseases and those associated with nutritional problems. ${ }^{22}$

The acquisition of competences in public health oriented to the understanding of the phenomenon of aging and old age, and the design, implementation and evaluation of interventions that comply with national and international regulations aimed at having an active and healthy aging, will enable graduates to actively participate in the necessary and essential changes of the different sectors, institutions and society showing a balance between the conceptual aspects of public health and the practical aspects that are acquired with the active participation of the community. ${ }^{22}$

\section{CONCLUSIONS}

The health personnel should focus on the life quality of people at this age. Palliative care is important in this population group because it improves the standards of humanization, regarding the attention they must be given in terms of health and emotions. In public health, older adults are increasing in recent years entailing not only population growth but also diseases inherent to their age, becoming a vulnerable population in terms of the care they need leading to higher costs, physical wear and tear of their caregivers, emotional problems, among others, making abandonment an option in most cases.

\section{REFERENCES}

1. Programa conjunto de las Naciones Unidas sobre el VIH/SIDA (ONUSIDA). Informe mundial: informe de ONUSIDA sobre la epidemia mundial de SIDA 2012. Ginebra: ONUSIDA; 2012. TechnicalReport Series: ONUSIDA. JC2417S

2. Programa conjunto de las Naciones Unidas sobre el VIH/SIDA (ONUSIDA). Informe mundial: informe de ONUSIDA sobre la epidemia mundial de SIDA 2013. Ginebra: ONUSIDA; 2013. TechnicalReport Series: ONUSIDA/JC2502/1/S

3. Sudharshan S, Biswas J. Introduction and immunopathogenesis of acquired immune deficiency syndrome. Indian J. Ophthalmol. 2008;56(5):357-62.

4. Araújo LF. El origen del sida después de tres décadas desde sus primeros diagnósticos. Psicología \& Sociedade2014;26(1):248-249.

5. Soler-Palacín P, Provens AC, Martin-Nalda A, Espiau M, FernandezPolo A, Figueras C. Indicadores de calidad asistencial para la atención 
de personas que viven con los virus de la inmunodeficiencia humana, adaptados a la edad pediátrica. Enferm. Infecc. Microbiol. Clin. 2014;32(3):160-169.

6. Ministerio de Salud y protección social de Colombia (MINSALUD). Guía de práctica clínica basada en la evidencia científica para la atención de la infección por $\mathrm{VIH} / \mathrm{Sida}$ en adolescentes con 13 años o más y adultos. Bogotá, Colombia: MINSALUD; 2014. [Access 2018 February 11]. Available from: http://gpc.minsalud.gov.co/gpc_sites/Repositorio/Otros_conv/GPC_ VIH_adolescentes/gpc_vih_adolescentes_completa.aspx

7. Pulido Álvarez A. Reseñas: Guías de promoción de la salud y prevención de enfermedades en la salud pública, Modelo de gestión programática y guía para el manejo del VIH/SIDA, Guía para el manejo y modelo de prevención y control de la enfermedad renal crónica. Rev. Gerenc. Polit. Salud 2007;6(13):169-173.

8. Arrivillaga-Quintero M. Análisis de las barreras para la adherencia terapéutica en mujeres colombianas con VIH/Sida: cuestión de derechos de salud. Salud Pública Méx. 2010;52(4):350-356.

9. Magis C, Parrini R. Nuestra Epidemia El SIDA en México 1983-2002. In: Magis C, Barrientos H, Editors. VIH/SIDA y Salud Pública Manual para personal de salud. México: Centro Nacional para la Prevención y el control del VIH/SIDA (CENSIDA); 2009. p. 37-46.

10. Centro Nacional para la Prevención y el control del VIH/SIDA (CENSIDA). Guía de prevención, diagnóstico y tratamiento de las ITS. México: FUNSALUD; 2011. [Access 2018 February 7]. Available from: https://www.gob.mx/censida/documentos/guia-deprevencion-diagnostico-y-tratamiento-de-las-its.

11. Programa conjunto de las Naciones Unidas sobre el VIH/SIDA (ONUSIDA). Estimaciones sobre el VIH y el sida 2016 [homepageonthe Internet]. Colombia: ONUSIDA; c2016 [updated 2017; cited 2018 February 13]. Available from: http://www.unaids.org/es/regionscountries/countries/colombia.

12. Instituto Nacional de Salud de Colombia. BoletínEpidemiológico 2017 [homepage on the Internet]. Colombia: MINSALUD; c2017 [updated 2018; cited 2018 February 13]. Available from: http://www.ins.gov.co/buscador-eventos/Paginas/Vista-BoletinEpidemilogico.aspx.

13. Centro Nacional para la Prevención y el control del VIH/SIDA (CENSIDA). Resumen de la Vigilancia Epidemiológica del Registro Nacional de Casos SIDA al 15 de noviembre de 2016 [homepageonthe Internet]. México: CENSIDA; c2016 [updated 2016; cited 2018 February 8]. Available from http://www.censida.salud.gob.mx/descargas/epidemiologia/RN_DIA _MUNDIAL_2016a.pdf.

14. Programa conjunto de las Naciones Unidas sobre el VIH/SIDA (ONUSIDA). Orientaciones terminologícas [homepage on the Internet]. Ginebra: ONUSIDA; c2011. [updated 2011; cited 2018 February 15]. Available from: http://files.unaids.org/en/media/unaids/contentassets/documents/unai dspublication/2011/JC2118_terminology-guidelines_es.pdf.

15. Calderón CAA, Botero JC, Bolaños JO, Martínez RR. Sistema de salud en Colombia: 20 años de logros y problemas. Ciênc. Saúde Coletiva. 2011;16(6):2817-2828.

16. Fondo Colombiano de Enfermedades de alto costo (Cuenta de alto costo). Situación del VIH en Colombia 2015 [homepageonthe Internet]. Colombia: Cuenta de alto costo; c2015. [updated 2015; cited 2018 February 15]. Available from: https://cuentadealtocosto.org/site/images/Publicaciones/Situacio\%C C\%81n\%20del\%20VIH\%20en\%20Colombia\%202015.pdf.
17. Gómez-Dantés O, Sesma S, Becerril VM, Knaul FM, Arreola H, Frenk J. The health system of Mexico. Salud Pública Méx. 2011;53 (Suppl. 2):220-232.

18. Ministerio de Salud y protección social de Colombia (MINSALUD). Calidad y Humanización de la atención [homepageonthe Internet]. Colombia: MINSALUD; c2017. [updated 2017; cited 2018 February 16]. Available from: https://www.minsalud.gov.co/salud/publica/PI/Paginas/calidadhumanizacion-atencion.aspx

19. Secretaria de salud de México. Programa de acción Especifico Respuesta al VIH, SIDA e ITS 2013 - 2018 [homepageonthe Internet]. MEXICO: Secretaria de salud de Mexico; c2014. [updated 2014; cited 2018 February 16]. Available from: http://www.censida.salud.gob.mx/descargas/acerca/PAE_2013_2018 _AUTORIZADA.pdf

20. Uribe AF, Orcasita LT. Evaluación de conocimientos, actitudes, susceptibilidad y auto eficacia frente al VIH/SIDA en profesionales de la salud. Av. Enferm. 2011;29(2):271-284.

21. Trejos Herrera AM, Tuesca Molina RJ, Mosquera Vásquez M. Niñez afectada con VIH/SIDA: Uso y acceso a servicios de salud en cinco ciudades colombianas. Salud Uninorte 2011;27(2):171-184.

22. Tamayo-Zuluaga B, Macías-Gil Y, Cabrera-Orrego R, Henao-Pelaéz JN, Cardona-Arias JA. Estigma social en la atención de personas con $\mathrm{VIH} / \mathrm{Sida}$ por estudiantes y profesionales de las áreas de la salud, Medellín, Colombia. Rev.Cienc. Salud.2015;13(1):9-23.

23. Herrera C, Campero L, Caballero M, Kendall T. Relación entre médicos y pacientes con VIH: Influencia de apego terapéutico y calidad de vida. Rev. Saúde Pública 2008;42(2):249-55.

24. Infante $\mathrm{C}$, Zarco A, Magali-Cuadra S, Morrison K, Caballero M, Bronfman M, et al. El estigma asociado al VIH/SIDA: el caso de los prestadores de servicios de salud en México. Salud Pública Mex.2006;48:141-150 